ISSN: 0213-2079 - ISSN electrónico: 2386-3889

DOI: https://doi.org/10.14201/shhmo2021431293322

\title{
LAS HERMANDADES DE CIEGOS ORACIONEROS EN LA ESPAÑA MODERNA: ENTRE LA POBREZA Y EL PRIVILEGIO
}

\section{The brotherhoods of blind prayer singers in Early Modern Spain: between poverty and privilege}

\section{Juan GOMIS}

Universidad Católica de Valencia

juan.gomis@ucv.es

\section{Eva ROMERO}

Universidad Católica de Valencia

eva.romero@ucv.es

Fecha de recepción: 03/11/2020

Fecha de aceptación: 16/03/2021

\section{INTRODUCCIÓN ${ }^{1}$}

Este artículo aborda el estudio de las hermandades de ciegos que existieron en España desde los siglos bajomedievales hasta mediados del siglo XIX, poniendo el foco en el período altomoderno. Nos centramos así en el momento de fundación de las cofradías y en su primer período de andadura, durante el que se apropiaron del rezo de oraciones como oficio, regulándolo y ejerciéndolo en exclusiva al amparo de las autoridades.

1. Este trabajo se ha realizado en el marco de los proyectos de investigación PCI 2019103749, financiado por el Ministerio de Ciencia, Innovación y Universidades, y GV/2020/207, financiado por la Conselleria d'Innovació, Universitats, Ciència i Societat Digital (Generalitat Valenciana).

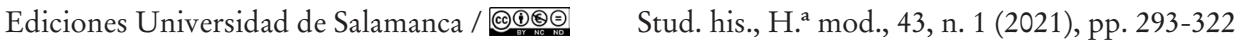


JUAN GOMIS Y EVA ROMERO

LAS HERMANDADES DE CIEGOS ORACIONEROS EN LA ESPAÑA MODERNA:

ENTRE LA POBREZA Y EL PRIVILEGIO

La figura del ciego oracionero o coplero, muy presente en la literatura áurea, ha recibido la atención de la historiografía en los últimos años (Cátedra, 2002; Iglesias Castellano, 2016 y 2017). Estos estudios, sin embargo, se han basado en casos particulares (como el ciego Mateo de Brizuela), o han tratado de las actividades desempeñadas por los ciegos como mediadores culturales (invención de noticias, composición de romances, canto callejero, venta de papeles) haciendo hincapié en su quehacer individual, sin encuadrarlos en las corporaciones de las que fueron miembros con mucha frecuencia. Es este elemento asociacionista el que pretende subrayar este artículo, con la esperanza de demostrar que constituye un aspecto clave para la comprensión de la «subcultura del ciego» en España.

Si bien existen algunas investigaciones sobre las hermandades de ciegos (Botrel, 1973 y 1974; Espejo, 1925; Gomis, 2010) estas se han centrado sin excepción en una cofradía particular en un momento particular, sin ofrecer un panorama general de la red de corporaciones desplegada entre los siglos XIV y XVI en el territorio hispánico. Este artículo propone una aproximación al fenómeno asociacionista de los ciegos en su conjunto, estudiando primero las dos oleadas de fundaciones que se dieron en los siglos XIV y XVI, dando cuenta en segundo lugar de las evidencias disponibles sobre la existencia de cofradías de ciegos en diversas ciudades españolas cuyos orígenes permanecen en la oscuridad, y analizando finalmente la actividad oracionera apropiada de modo corporativo por los ciegos.

Las páginas que siguen se sitúan, de este modo, en una encrucijada de intereses y líneas historiográficas que alejan el tema de la mera anécdota, curiosidad o pintoresquismo. El asunto entronca directamente, desde luego, con los «disability studies», cultivados de modo creciente por la historiografía internacional, particularmente anglosajona, aunque todavía con un desarrollo escaso en España. La finalidad asistencial perseguida por los ciegos con su estrategia asociacionista, apoyada por las autoridades civiles en su renovado afán por combatir la mendicidad desde la Baja Edad Media, sitúa el tema en la órbita de la historia social y, en concreto, de los estudios sobre el pauperismo. Finalmente, la mediación cultural ejercida por los ciegos hermanados como rezadores, copleros o vendedores de pliegos sueltos, pone el foco en los aspectos performativos y los procesos de apropiación y negociación de los significados, tan caros a la historia cultural.

\section{LAS HERMANDADES DE CIEGOS EN ESPAÑA}

\subsection{Un fenómeno europeo}

El asociacionismo de los ciegos se encauzó a través de la fundación de hermandades en numerosas ciudades, algunas de las cuales hunden sus raíces en la Edad Media. En esto, España no constituye un caso excepcional: la tendencia de los ciegos a organizarse en cofradías fue común en Europa y, aunque se trata de un campo

Ediciones Universidad de Salamanca / అ@@ Stud. his., H. ${ }^{a}$ mod., 43, n. 1 (2021), pp. 293-322 
JUAN GOMIS Y EVA ROMERO

LAS HERMANDADES DE CIEGOS ORACIONEROS EN LA ESPAÑA MODERNA:

ENTRE LA POBREZA Y EL PRIVILEGIO

de estudio poco trabajado, conocemos su existencia en un importante número de ciudades. En Francia encontramos una de las congregaciones de ciegos más antigua y conocida: el hospital de los Quinze-Vingts de París, fundado a mediados del siglo XIII por Luis IX, y cuyo establecimiento se situó hasta 1780 cerca de la Puerta de Saint-Honoré, fuera de la muralla de Felipe Augusto (Weigand, 2003: 28-33). A pesar de que su nombre puede hacer pensar en una institución asistencial, en realidad el Hôpital des Quinze-Vingts funcionó como una auténtica congregación de ciegos, cuyo funcionamiento recuerda, según Zina Weygand, al de las órdenes mendicantes. Los asociados vivían bajo una regla común, tenían una estructura organizativa definida (maestro, ministro, seis jurados), juraban guardar los secretos de la confraternidad, gozaban de privilegios reales y eclesiásticos, y tenían como funciones el rezo por la familia real y todos sus benefactores, la asistencia a los condenados a muerte, el velatorio de aquellos difuntos que así lo reclamasen, y sobre todo la mendicidad. Otro hospital, inspirado en el de los Quinze-Vingts, fue fundado en Chartres en 1292 por Renaud Barbou el Viejo. En Sarrant, pueblo de la Gascuña, existió propiamente una cofradía de ciegos, bajo la advocación de Nuestra Señora de la Visitación (Gilard-Fito, 2002). De origen desconocido, los hermanos de esta congregación se dedicaban a la música, animando las celebraciones públicas y privadas de la región. Los ciegos encontraron en Sarrant asilo y exenciones fiscales, que debieron de constituir un reclamo para instalarse en el pueblo e ingresar en la hermandad, donde iniciaban un período de aprendizaje musical. Es significativo que muchos de estos rasgos característicos (los privilegios, el oficio de músicos, la enseñanza del tañido de instrumentos, incluso el propio nombre de la cofradía) fueran compartidos, como veremos, por las hermandades de ciegos españolas, entre las que la de Madrid ostentaba también el título de Nuestra Señora de la Visitación. Según se subrayará en las páginas que siguen, los contactos e intercambios de información y experiencias entre las corporaciones españolas fueron constantes. Al parecer, estos incluso pudieron atravesar los Pirineos.

En el contexto germano, Irina Metzler (2013:179-181) ha localizado una corporación de ciegos en Estrasburgo, fundada en 1411. La hermandad donaba un cirio y hacía rezar una misa por el alma de cada hermano difunto, y desde 1469 permitió el ingreso a otro tipo de discapacitados. Existió otra cofradía para «pobres que viven de las oraciones, como lisiados, ciegos y otras gentes» en Zülpich, territorio del arzobispado de Colonia, fundada en 1454. Según Metzler, esta congregación estaba más cerca, en su estructura y funcionamiento, de las coetáneas hermandades de ciegos de Valencia y Barcelona (a las que nos referiremos seguidamente), que de cualquier otro tipo de gremio del norte de Europa. El objetivo de la hermandad de Zülpich era la ayuda mutua entre los hermanos, para lo cual sus ordenanzas establecían normas muy similares a las que veremos en las cofradías españolas: en caso de enfermedad de algún cofrade, sus compañeros debían mantenerle pidiendo limosnas para él, y si no podían quedarse a su lado hasta su completa recuperación,

Ediciones Universidad de Salamanca / 요 Stud. his., H. ${ }^{a}$ mod., 43, n. 1 (2021), pp. 293-322 
JUAN GOMIS Y EVA ROMERO

LAS HERMANDADES DE CIEGOS ORACIONEROS EN LA ESPAÑA MODERNA:

ENTRE LA POBREZA Y EL PRIVILEGIO

era prescriptiva la entrega de cuatro o dos chelines, dependiendo de la capacidad económica de cada hermano. Otra hermandad de ciegos y sordos fue fundada en Tréveris en 1437, con una finalidad común a la anterior: la asistencia mutua entre los hermanos en tiempos de escasez o enfermedad.

Italia concentró un considerable número de hermandades de ciegos: las encontramos en Génova (fundada en 1299), Venecia (1315), Florencia (1324), Padua (1358), Milán (1471), Bolonia (1566), Roma (1613), Siena (1624) y Palermo (1661) (Carnelos, 2016; Cessi, 1905; Cajani, 1979 y 1994; Zardin, 1996). Como afirma Laura Carnelos, a pesar de la fragmentación italiana y la diversidad de gobiernos locales, estas cofradías eran muy similares entre sí, tanto en su funcionamiento como en su estructura jerárquica. La jefatura de la hermandad la ostentaba el gastaldo, apoyado por uno o dos asistentes y uno o más consejeros; a estos cargos se les unían otros: el contable, los visitadores de enfermos y los que cobraban los pagos. Como en España, las sedes de estas congregaciones estaban ubicadas en las iglesias, donde tenían sus altares y capillas: durante dos siglos la compañía de ciegos veneciana tuvo su altar en la misma iglesia de San Marcos, y desde 1595 en San Moisés (en el lado opuesto de la plaza); la hermandad de Padua en la basílica de San Antonio; la cofradía de Milán tenía su sede en la iglesia de San Salvador en Xenodochio y su capilla en la catedral; la cofradía romana contó con su espacio en la iglesia del Hospital de San Sixto, la mayor institución asistencial para los pobres de la ciudad. Todas ellas contaron con la protección de algún alto cargo político o religioso, que aprobaba sus ordenanzas y ratificaba los nuevos capítulos que se iban añadiendo con el paso del tiempo. Su objetivo, como en las corporaciones de tierras germanas, fue garantizar la solidaridad entre los hermanos en caso de pobreza, enfermedad y muerte, así como asegurar una forma legal de mendicidad autorizada: los cofrades podían pedir dinero por las calles de su propia ciudad a condición de que se comportasen de modo adecuado.

Finalmente, aunque tardía en relación con las anteriores, Portugal contó también con una cofradía de ciegos. Se trata de la Sociedade do Menino Jesus dos Homens Cegos, fundada en Lisboa en 1749 (Guedes, 2005: 28; Romeiras, 2014). Su sede se ubicó en un primer momento en la iglesia de San Jorge, pasando después a la de San Martín. Un decreto real les concedió el monopolio sobre la venta de impresos populares por las calles de Lisboa, así como el rezo de oraciones de puerta en puerta, privilegios que esta hermandad portuguesa compartió con las cofradías españolas, existentes desde varios siglos atrás.

Así pues, el fenómeno de las hermandades de ciegos en España no puede caracterizarse, ni mucho menos, como excepcional. Ahora bien, es cierto que España e Italia concentraron en sus territorios un número de cofradías de ciegos muy superior al del resto de países europeos. Las razones de esta ebullición corporativa de los ciegos en ambas penínsulas están lejos de alcanzarse, y no constituyen propiamente el objeto de este trabajo. Lo cierto es que el surgimiento de estas congregaciones en

Ediciones Universidad de Salamanca / 요 Stud. his., H. ${ }^{a}$ mod., 43, n. 1 (2021), pp. 293-322 
JUAN GOMIS Y EVA ROMERO

LAS HERMANDADES DE CIEGOS ORACIONEROS EN LA ESPAÑA MODERNA:

ENTRE LA POBREZA Y EL PRIVILEGIO

territorio hispánico fue muy temprano, y tanto su expansión a numerosas ciudades como su perdurabilidad (hasta el siglo XIX) subrayan la capacidad asociativa de los ciegos y que los beneficios derivados de su corporativismo fueron lo suficientemente importantes como para salvaguardarlo a lo largo de los siglos.

\subsection{Los inicios: Valencia y Barcelona}

La fundación de hermandades de ciegos en España se dio en dos fases. La primera se produjo en la primera mitad del siglo XIV, con la aparición de las cofradías de Valencia y Barcelona, las congregaciones más antiguas ${ }^{2}$. La segunda fue más tardía (siglo XVI), y tuvo como escenario el territorio castellano, con la fundación de hermandades en Madrid, Sevilla, Córdoba, Málaga, Granada, Cádiz y Murcia, a las que hay que añadir la de Zaragoza en tierras aragonesas.

Hasta donde sabemos, la primera hermandad de ciegos en España fue la de Valencia, fundada en 1329 (Gomis, 2010). En ese año el rey Alfonso IV aprobó sus ordenanzas, junto con las de las cofradías de çabaters, aluders i pergaminers, Santa Catalina, corregers y pellicers. Los ciegos, pues, se sumaron al renovado impulso protagonizado por las hermandades de la ciudad, consecuencia de la creciente participación de los artesanos en la vida municipal valenciana (Benítez Bolorinos, 1998 y 2006). Sin embargo, de la letra del propio documento fundacional ${ }^{3}$ se infiere que la hermandad de ciegos existía ya anteriormente, pues había sido abolida junto con las demás (a excepción de la de San Jaime) unos años antes. Ahora, en 1329, una vez derogada la prohibición, fue restaurada.

Los capítulos aprobados por Alfonso IV detallan las finalidades que los ciegos perseguían con la fundación de la hermandad. En primer lugar, de tipo religioso: por un lado, a la congregación le era permitido mantener un cirio encendido en la iglesia de la Santa Cruz, la cual, afirmaban las ordenanzas, «hia cremat be $X V$ anys» (es decir, llevaban 15 años con esta práctica, otra prueba de que los orígenes de la hermandad se retrotraen más allá de 1329). Por otro lado, todos los cofrades debían reunirse el primer martes después de San Martín para practicar la limosna, alimentando cada uno a un pobre («tres diners de pa, mija liura de molto et dos diners de vy»). Finalmente, debían ordenar misas en la iglesia de la Santa Cruz con el producto de sus limosnas. Este tipo de capítulos religiosos y caritativos eran comunes en el resto de hermandades. La segunda clase de capítulos, por el

2. Sobre una supuesta cofradía fundada en Toledo para los veteranos de la batalla de las Navas de Tolosa que habían quedado ciegos, no conocemos ninguna evidencia documental (Fernández Iglesias, 2008: 186).

3. Archivo de la Corona de Aragón (ACA), Cancillería, Registros n. ${ }^{\circ}$ 479. La trascripción del documento en Bofarull y de Sartorio, 1876: 102-105 (vol. I).

Ediciones Universidad de Salamanca / @®@@ Stud. his., H. ${ }^{a}$ mod., 43, n. 1 (2021), pp. 293-322 
JUAN GOMIS Y EVA ROMERO

LAS HERMANDADES DE CIEGOS ORACIONEROS EN LA ESPAÑA MODERNA:

ENTRE LA POBREZA Y EL PRIVILEGIO

contrario, eran peculiares y denotaban la finalidad principal de la cofradía de ciegos: la ayuda mutua entre los hermanos, tal y como hemos visto en otras hermandades europeas. Ayuda en la enfermedad: si algún cofrade encontraba por los caminos a otro enfermo, debía visitarlo y darle la mitad de sus limosnas durante ocho jornadas. En caso de que el paciente muriera en dicho plazo, el hermano se ocuparía de amortajarlo. Si el enfermo se encontraba en la ciudad, los compañeros lo velaban por turnos cada tarde y se preocupaban de darle parte de sus limosnas. Ayuda en la dificultad: si un hermano era encontrado sin guía, era preceptivo compartir con él el lazarillo durante quince días. Y ayuda en la muerte: los cofrades debían asistir al entierro de los compañeros, así como al de sus esposas, se encendían dos cirios el día del fallecimiento y en los aniversarios, y cada hermano debía rezar cien padres nuestros y ave marías por el alma del difunto. Para el sustento de la hermandad, los cofrades pagaban una cuota anual de doce dineros.

Por su parte, la cofradía de Barcelona fue fundada diez años después, en 1339. $\mathrm{Su}$ relación con la congregación valenciana fue estrecha desde sus orígenes y, de hecho, sus ordenanzas fundacionales, aprobadas por Pedro el Ceremonioso, son muy similares (Bofarull y de Sartorio, 1876: 145-149). Eran novedosos los capítulos dedicados a la organización del gobierno de la cofradía, inexistentes en el caso de la congregación valenciana: se establecían multas para los cofrades que no aceptasen el cargo de mayoral (quince sueldos), así como para aquellos que no obedeciesen las decisiones de la dirección (dos libras de cera). Estas novedades denotan una estructura organizativa más compleja, quizá derivada de los diez años de experiencia de la cofradía vecina: especialmente, la incorporación de las multas por las infracciones de los capítulos y la normativa sobre el gobierno de la congregación son indicativas de esta evolución corporativa.

La hermandad de Valencia se desarrollaría orgánicamente en esta misma dirección a lo largo del siglo XIV. La cofradía recibió nuevos capítulos en 1353, 1392 y 1407 (Benítez Bolorinos, 1998: 45-47). En estas sucesivas ordenanzas se aprecia una gradual evolución en la organización de la corporación, que fue creciendo en complejidad. Así, las cuotas anuales aumentaron sensiblemente (un sueldo en 1353 y cuatro en 1392) y se incluyeron, como en Barcelona, las multas como eficaz medio recaudatorio: el cofrade que no asistiese a la reunión de capítulo pagaría una libra de cera, y tres sueldos en caso de encontrarse fuera de la ciudad sin avisar (1407). La exigencia de la entrega de la cuota anual era asimismo mayor, pues su no cumplimiento implicaba ser puesto ante el Justicia civil. Además, la moralidad de los companys entró a formar parte de los requisitos de entrada y permanencia en la hermandad: el concubinato era penado con la expulsión, así como también arrebatar a otro cofrade su lazarillo (como también se estipulaba en las ordenanzas de Barcelona).

Ediciones Universidad de Salamanca / @®@@ Stud. his., H. ${ }^{a}$ mod., 43, n. 1 (2021), pp. 293-322 
JUAN GOMIS Y EVA ROMERO

LAS HERMANDADES DE CIEGOS ORACIONEROS EN LA ESPAÑA MODERNA:

ENTRE LA POBREZA Y EL PRIVILEGIO

En cuanto a los capítulos religiosos, se establecía como novedad la reunión de los cofrades en la casa de la hermandad cada martes de la octava de Pascua, para marchar luego de dos en dos a la iglesia de la Santa Cruz a oír misa. Además de la lámpara que Alfonso IV les permitió mantener encendida, en 1392 los ciegos obtuvieron un privilegio para tener otro cirio en la misma iglesia por el alma de todos sus benefactores y para los domingos y las festividades. En estas mismas ordenanzas, por otro lado, la cofradía se situó bajo la advocación de la Vera Creu y no, como anteriormente, bajo la de la Virgen. Este cambio sería solicitado formalmente en los capítulos de 1407. Así pues, desde comienzos del siglo XV y hasta su disolución en el XIX, la hermandad valenciana sería conocida como «cofradía de pobres ciegos de la Vera Creu».

Hay otro aspecto apreciable en la sucesión de ordenanzas recibidas por esta hermandad de ciegos a lo largo del siglo XIV. Nos referimos al creciente poder económico que la corporación comenzó a desarrollar en este período: nos habla de ello tanto la existencia de un alberch en la parroquia de la Santa Cruz destinado a las reuniones, comidas y capítulos de los cofrades, como la licencia que estos obtuvieron en 1392 para comprar censales, rentas y otros bienes de realengo, u obtenerlos a través de donaciones o testamentos, en cantidades que no superaran las trescientas libras. Más allá de sus finalidades caritativas y asistenciales, la hermandad se revelaba en los albores del siglo XV como un cuerpo organizado capaz de generar un patrimonio que sirviera a los intereses de sus asociados.

El desarrollo de la hermandad de Barcelona durante su primer siglo de existencia está sumergido en las sombras, pues no hemos localizado fuentes primarias de ese período. Según una nota publicada en el Correo Catalán en $1892^{4}$, relativa a la "Capilla del Espíritu Santo de Barcelona y cofradías en ella establecidas», la cofradía estuvo durante esos primeros años bajo la advocación de San Martín. Sabemos por la misma fuente que el Infante don Juan de Aragón aprobó en 1365 la fundación de otra hermandad, esta vez de lisiados y tullidos, bajo la advocación de San Andrés. Martín el Humano confirmó los privilegios de ambas cofradías en 1401 y 1397, respectivamente. Al parecer, el volumen de la hermandad debió aumentar a comienzos del siglo XV, pues en 1416 Alfonso IV ordenó que todos los ciegos mendicantes de Barcelona ingresaran en la congregación, y en 1433 María de Aragón aprobó la unión de las cofradías de San Martín y San Andrés, situándose la refundada hermandad bajo la advocación del Espíritu Santo. Esta información es de gran relevancia, pues apunta a la unión de personas con discapacidades diversas

4. Correo Catalán, año XVII (jueves, 9 de junio de 1892), pp. 4-6. El autor de la nota es Antonio Aymar y Puig. Encontramos los mismos datos en el impreso Confirmación de los privilegios y prerogativas del Gremio y Cofradía de Sto. Espíritu y Ntra. Sra. De la Fuente de la Salud, Barcelona, Imprenta de la V. Torrás, 1868.

Ediciones Universidad de Salamanca / @®@@ Stud. his., H. ${ }^{a}$ mod., 43, n. 1 (2021), pp. 293-322 
en una sola congregación, lo que podría entenderse como un intento por parte de estas de unir esfuerzos para ganar mayor capacidad de acción y visibilidad social. En algún documento de la hermandad de la Vera Creu de Valencia asoma también la presencia en la congregación de otros discapacitados no ciegos ${ }^{5}$, lo que reforzaría esa interpretación. Sin embargo, en la inmensa mayoría de los documentos consultados sobre ambas cofradías, desde su fundación hasta el siglo XIX, el peso de los hermanos ciegos es aplastante, sin que ni siquiera se mencione la inclusión de otros cofrades, por lo que creemos que, a pesar de los intentos de las autoridades civiles por reunir en una misma congregación a todos los «estropeados» de una ciudad, los ciegos terminaron por hacerse con el control de la misma. Este predominio abre interrogantes, de difícil respuesta, sobre las causas de la marginación de otras minorías discapacitadas por parte de los ciegos, o a nivel general, sobre las razones que explican la extraordinaria capacidad asociativa de estos últimos, superior, al parecer, a la de otros colectivos.

Así pues, durante sus primeras décadas de existencia, las cofradías de ciegos de Valencia y Barcelona consolidaron progresivamente su situación: con la aprobación de sucesivos nuevos capítulos afinaron aspectos relativos a su estructura, composición y funciones; la ratificación de estas modificaciones de las ordenanzas por diferentes monarcas constituyó una garantía de que ambas corporaciones contaban con el apoyo de las autoridades; la finalidad asistencial y de ayuda mutua, que constituyó el principal impulso de los ciegos para la creación de la hermandad, fue subrayada por las sucesivas normativas, y sin duda constituyó la principal razón para el mencionado apoyo que las monarquías brindaron a las cofradías. Estas constituyeron, de hecho, un elemento más dentro del complejo ámbito asistencial existente ya a finales de la Edad Media, junto con los monasterios y conventos, las fundaciones pías, los montes de piedad, los hospitales y los mecanismos informales de asistencia familiar, vecinal o laboral. Apoyando el asociacionismo de los ciegos, el poder civil se beneficiaba de la asistencia que estos se prestaban unos a otros a través de sus hermandades, lo que permitía aliviar la situación miserable que con frecuencia sufría este colectivo.

\subsection{El siglo XVI: expansión del fenómeno asociacionista}

Cuando las hermandades de la Vera Creu y del Sant Esperit llevaban más de dos siglos de existencia, se produjo una segunda oleada de fundaciones de cofradías de ciegos a lo largo del siglo XVI. Aunque la mayoría de estas nuevas hermandades

5. Es el caso del privilegio real concedido por Fernando II en 1479, donde se menciona como miembros de la hermandad a «algunos pobres hombres ciegos y otras personas miserables» (Archivo Histórico Municipal de Valencia-AHMV-, MC A-41, f. 283r-285v).

Ediciones Universidad de Salamanca / @®@@ Stud. his., H. ${ }^{a}$ mod., 43, n. 1 (2021), pp. 293-322 
JUAN GOMIS Y EVA ROMERO

LAS HERMANDADES DE CIEGOS ORACIONEROS EN LA ESPAÑA MODERNA:

ENTRE LA POBREZA Y EL PRIVILEGIO

fueron castellanas, la primera en fundarse (o al menos de la que tenemos noticia) seguía perteneciendo a la Corona de Aragón, en lo que quizá podemos ver la influencia de las cercanas congregaciones de Valencia y Barcelona. Se trata de la cofradía de la Santísima Transfiguración de Nuestro Redentor Jesucristo de Zaragoza, fundada en 1537 y ubicada en el Monasterio de Nuestra Señora del Carmen. En realidad, no conocemos su fecha exacta de fundación, pues sus primeras ordenanzas indican que la hermandad ya estaba en funcionamiento, y que en 1537 los cofrades consideraron simplemente «haber necesario de tener y ser regida por ordinaciones según que otras cofradías, por el bien de dicha Cofradía y salud de nuestras ánimas y de todos nuestros difuntos» ${ }^{6}$. Las ordenanzas, aprobadas por los jurados de la ciudad de Zaragoza, dictaban las consabidas normas sobre aspectos organizativos y religiosos, pero incorporaban como novedad varios capítulos centrados en la regulación del rezo de oraciones, oficio atribuido a los ciegos hermanados, que analizaremos en el siguiente apartado. Dejando estos de lado, llama la atención en estas primeras ordenanzas de la cofradía zaragozana la ausencia de cualquier referencia a la ayuda mutua entre los hermanos que, sin embargo, como hemos visto, eran mayoritarias en los estatutos de las hermandades de Valencia y Barcelona. La sustitución de los capítulos destinados a la asistencia entre los ciegos por otros de tipo profesional es indicativa, en nuestra opinión, del cambio de rumbo que emprendieron las hermandades de ciegos, virando de asociaciones de ayuda mutua a gremios dedicados a una actividad profesional. El hecho de que las nuevas ordenanzas que la cofradía de la Santísima Transfiguración redactó en 1549 y 1602 se centraran, de nuevo, en la regulación del rezo de oraciones, incide en este viraje, que analizaremos en el siguiente apartado ${ }^{7}$.

En julio de 1581, el día de la Visitación de la Virgen, tres ciegos de origen gallego fundaron la hermandad de Nuestra Señora de la Visitación y Ânimas del Purgatorio, con sede en el convento de los Carmelitas Descalzos de Madrid (Botrel, 1973: 417-482). Según Botrel, las finalidades perseguidas por los ciegos con la fundación de la hermandad fueron, como venía siendo tradicional, de tipo religioso (hacer decir misas por las almas del Purgatorio y de los hermanos difuntos) y asistencial (ocuparse de los entierros de los cofrades, pagar como dote de sus hijas cien reales «y lo demás que pareciese a los hermanos para contraer matrimonio») (Botrel, 1973: 422, nota). Sin embargo, como novedad con respecto a las hermandades analizadas, un tercer tipo de finalidad perseguida por Fernando Alonso Ramos, Simón de Benavides y Andrés Díaz (los tres ciegos fundadores) fue constituir un capital social inicial que les permitiera realizar su labor asistencial: «entresimismos dando cada uno de su casa y hacienda la cantidad de maravedís que podía vinieron a adquirir y a juntar

6. Archivo Municipal de Zaragoza (AMZ), Libro de Actas, 1537.

7. AMZ, Libro de Actas, 1549 y 1602.

Ediciones Universidad de Salamanca / @®@@ Stud. his., H. ${ }^{a}$ mod., 43, n. 1 (2021), pp. 293-322 
de caudal con que comprar una casa... en la calle de San Antón» (Botrel, 1973: 421). Esta propiedad fue arrendada y, a la altura de 1614, aportaba a la congregación 440 reales anuales. Las bases financieras de la cofradía madrileña recuerdan a las mencionadas de la hermandad de la Vera Creu, con la diferencia de que esta última fue componiendo este capital durante su primer siglo de andadura, mientras que la primera lo tuvo como objetivo prioritario desde sus mismos inicios. De nuevo, tal y como hemos visto con la congregación zaragozana, las nuevas fundaciones de ciegos surgidas en el siglo XVI muestran un grado de sofisticación desconocido en las medievales. Al igual que la hermandad de la Santísima Transfiguración, la madrileña también se ocupará bien pronto de regular sus actividades profesionales, tal y como veremos más adelante.

Otra cofradía de ciegos surgida en el siglo XVI y de la cual conservamos sus ordenanzas fundacionales es la de Sevilla. Se trata de la hermandad de la Santísima Trinidad de ciegos y vistosos, sita en el convento de Trinitarios descalzos de la ciudad, y conocemos sus primeros estatutos gracias a una copia que presentaron en 1826, con el fin de que Fernando VII las ratificara ${ }^{8}$. Según el documento, se trataba del «testimonio de las ordenanzas con que se han regido hasta el día, aprobadas por el Provisor eclesiástico de aquel arzobispado en el año de mil quinientos noventa y siete, sin que hayan sido interrumpidas en lo más mínimo por el loable objeto con que se hicieron». En consonancia con lo visto en Madrid y Zaragoza, desde el mismo preámbulo de los estatutos de 1597 se establecía como principal finalidad de la hermandad de Sevilla la actividad profesional de los cofrades, y no la asistencia mutua. Así, los doce ciegos fundadores ${ }^{9}$ afirmaban que la creación de la congregación redundaría

no solo en honra y gloria de Dios nuestro Señor, mas en gran utilidad y provecho espiritual y temporal nuestro, siendo nuestras oraciones más bien recibidas en el pueblo, despertándose en él un nuevo fervor para oírlas con mayor devoción y atención, la cual como todos sabemos ha venido a tan gran disminución, aun el crédito y opinión en que nos tenían a causa de haber entre nosotros algunos defectos y excesos, para cuya extirpación y reformación de ellos habemos sido congregados.

Así pues, el objetivo declarado por los ciegos para fundar la hermandad se refería, de nuevo, al rezo de oraciones, y no tanto a la ayuda mutua entre los cofrades. En contraste con las hermandades anteriores, la sevillana no cerraba la puerta a las

8. Archivo General del Arzobispado de Sevilla (AGAS), Justicia, Hermandades, Signatura 09817, Expediente 10.

9. Conocemos sus nombres: Pedro Miguel, Gabriel de la Cueva, Lázaro Cortés, Antonio Hernando, Juan de Santillana, Alonso Romero, Juan Fernández, Antonio de la Cruz, Bartolomé Sirgad, Antonio de Peralta, Juan Ponce y Martín Valero, «privados de la vista corporal».

Ediciones Universidad de Salamanca / 요 Stud. his., H. ${ }^{a}$ mod., 43, n. 1 (2021), pp. 293-322 
personas «de vista», si bien les impedía ser elegidos para los cargos de la asociación. Dado que, a la muerte de un cofrade, había «de heredar la vela - es decir, el lugar en la hermandad - el hijo o mujer de dicho hermano", fuera o no ciego, la cofradía decidió abrir sus puertas a todo aquel que quisiera ingresar en ella. De ahí el sobrenombre que en adelante tendría la congregación, «de ciegos y vistosos».

Los ciegos de Sevilla, sin embargo, ya estaban organizados en una hermandad con anterioridad a 1597. Así lo confirman diferentes documentos del siglo XVI, relativos al «hospital y cofradía de San Justo y San Pastor, que vulgarmente se llama y nombra de los ciegos»: un pleito de 1576 a propósito de las cuentas de esta congregación constata la existencia de unas ordenanzas («reales constituciones»), aprobadas en fecha desconocida ${ }^{10}$. Entre otros aspectos, los capítulos debían de cubrir la asistencia a los hermanos en caso de enfermedad, pues Sebastián Magaña acusaba al prioste, Pedro Rodríguez, de no haber pagado a la mujer de uno de ellos, postrado en cama, la limosna estipulada. Esta cofradía, anterior a la de la Santísima Trinidad, existía ya a la altura de 1526, según se colige de un documento de ingreso por el cual el ciego Juan de la Redondela entregaba 24 maravedíes anuales a Luis Fernández Cabrón, ciego, a cambio de «los privilegios de los dichos ciegos, porque goce de ellos según que los otros ciegos gozan, y me recibís por hermano en la hermandad de los dichos ciegos» (Gestoso y Pérez, 1910: 141-142). ¿Por qué razón una hermandad que ya contaba con una prolongada trayectoria a finales del siglo XVI fue sustituida por otra en 1597? Lo ignoramos. Sin embargo, es posible que procesos judiciales como el mencionado, que enfrentaban a cofrades entre sí o contra el gobierno de la congregación, estuvieran detrás de la disolución de la cofradía de los Santos Justo y Pastor. De hecho, así parecían sugerirlo los mismos ciegos en las ordenanzas de 1597, cuando en un capítulo advertían «que ningún prioste de ella pueda inventar pleito alguno ni gastos extraordinarios más que lo necesario por solo su parecer, sin acuerdo del cabildo». Así perseguían "prevenir el notable daño que de algunos pleitos y gastos impertinentes podrían redundar a esta santa cofradía». El pleito de 1576 se refería, precisamente, a los excesivos gastos que varios hermanos atribuían a la dirección de la hermandad, por lo que quizás los fundadores de la nueva cofradía estaban pensando en este y en otros conflictos similares cuando aludían a su conocimiento de los perjuicios que los pleitos por las cuentas podían generar a la congregación: «como consta por la experiencia que tenemos».

Poco más sabemos de esta primera cofradía de ciegos de Sevilla, fundada a comienzos del siglo XVI (si no antes). Del mismo modo, tampoco conocemos los documentos fundacionales del resto de hermandades que se crearon en España en esta segunda oleada. Sin embargo, contamos con fuentes primarias y secundarias

10. Archivo Histórico Provincial de Sevilla (AHPS), Real Audiencia, 29103, expediente 1.

Ediciones Universidad de Salamanca / అ@@ Stud. his., H. ${ }^{a}$ mod., 43, n. 1 (2021), pp. 293-322 
que demuestran la existencia de otras cofradías en diversas ciudades españolas, lo que nos permite ampliar el mapa del asociacionismo de los ciegos.

Sabemos que existió una hermandad de ciegos en Murcia: así lo afirma Pedro Díaz Cassou, fechando su establecimiento en 1588, cuando la asociación recibió un privilegio de Felipe II (Díaz Cassou, 1897: 10, nota). La titular de esta hermandad era Nuestra Señora de la Presentación. La sede estaba ubicada en la iglesia parroquial de San Pedro, y sus cabildos eran presididos por el párroco, única persona con vista que formaba parte de la congregación. Según Díaz Cassou, los ciegos murcianos recibieron diversos privilegios, que sin embargo no detalla. Un documento judicial de 1774 confirma la existencia de esta hermandad: por aquel entonces se desató un pleito entre el corregidor de Murcia y la cofradía de ciegos de la ciudad, a los que pretendía impedir «rezar y cantar, con instrumentos o sin ellos, oraciones, romances y demás que han practicado a imitación de los de esta Corte» ${ }^{11}$. La alusión a «los de esta Corte» se refería a los ciegos de Madrid, cuyas tradicionales actividades como músicos callejeros y vendedores de impresos eran conocidas e imitadas por los ciegos de Murcia.

En Córdoba encontramos la cofradía de la Encarnación del Hijo de Dios, sobre la que nos informan varios documentos judiciales de los siglos XVII y XVIII' ${ }^{12}$, así como otro con sus cuentas de los años 1749 y $1750^{13}$. En su obra Paseos por Córdoba Teodomiro Ramírez ofrece más información sobre esta hermandad, cuyo origen sitúa tempranamente, a finales del siglo XV:

La casa núm. 20 de la calle Alfaros ha estado durante siglos dedicada a hospital de ciegos pobres, a quienes recogían, considerándolos individuos de la cofradía formada principalmente con todos los que en Córdoba carecían del sentido de la vista: sus memorias alcanzan al año 1487, en que la erigieron en honor a la Encarnación del Hijo de Dios, Espíritu Santo, Santo Domingo, la Coronación de la Virgen María y San Sebastián mártir: sus reglas aparecen aprobadas en 1525; los pobres ciegos salían en rosario dos o tres noches en semana, recogiendo numerosas limosnas para el sostén de aquel pequeño hospital ${ }^{14}$.

De Burgos tenemos noticia del hospital de ciegos de San Miguel Arcángel, gracias a un documento de $1548^{15}$. No podemos estar seguros de si se trataba de una congregación de ciegos o de una institución asistencial: en el pleito sobre el que

11. Archivo Histórico Nacional (AHN), Consejos, Legajo 1231. La referencia la da Fernando Jiménez de Gregorio (1950-51: 227-228).

12. Archivo de la Real Chancillería de Granada (ARCG), Fondo Real Audiencia y Chancillería, Series de procedimientos civiles, Cajas 699 y 5375.

13. Archivo General del Obispado de Córdoba (AGOC), Signatura 6525.

14. Ramírez, 1873: 330-331.

15. ARCG, Registro de Ejecutorias, Caja 668, 16.

Ediciones Universidad de Salamanca / @®@@ Stud. his., H. ${ }^{a}$ mod., 43, n. 1 (2021), pp. 293-322 
JUAN GOMIS Y EVA ROMERO

LAS HERMANDADES DE CIEGOS ORACIONEROS EN LA ESPAÑA MODERNA:

ENTRE LA POBREZA Y EL PRIVILEGIO

nos informa la fuente aparecen varios ciegos que se querellan contra la hermandad de San Miguel, San Benito y Santa María Magdalena. Mencionan la fundación, hacía «doscientos y algo años poco más o menos», del «hospital de los ciegos, en que ellos fundasen su casa y hospital, donde se acogiesen y pusiesen su cabildo de la advocación del Señor San Miguel Ángel». La alusión parece apuntar a algo más que un simple establecimiento benéfico, y más aún cuando el documento nombra las casas, limosnas y censos que poseían los ciegos del hospital. Estos aparecen como agentes activos, gestores de los bienes del establecimiento, y no como meros pacientes atendidos en el hospital. De hecho, la hermandad de Córdoba también se constituyó, como acabamos de ver, como un hospital. Podríamos presumir, por tanto, que en Burgos existió una hermandad de ciegos, y si el documento en cuestión está en lo cierto, esta tendría a la altura de 1548 más de 200 años. Así pues, su antigüedad sería similar a la de las congregaciones de Valencia y de Barcelona. Sin embargo, no podremos consolidar estos indicios hasta que hallemos nuevos documentos sobre esta supuesta cofradía burgalesa.

En Málaga ubicamos la cofradía de Ánimas de Ciegos, cuya sede era una ermita edificada en los alrededores del convento de San Francisco de Asís. Desconocemos su fecha de fundación, siendo la documentación más antigua hallada sobre esta hermandad una manda testamentaria de 1573, por la que el cofrade Juan Jiménez expresaba su deseo de ser sepultado en la «capilla de las ánimas del Purgatorio que es en el Monasterio de San Francisco» (Llordén y Souvirón, 1969: 103-104). Al parecer, esta hermandad siguió los pasos de otras cofradías de ciegos, pues en 1789 trataba de impedir la venta de papeles a todo aquel que no fuera ciego, en virtud de una real provisión que les otorgaba el privilegio de «vender romances, almanaques, calendarios, diarios, tablas de jubileo y otros papeles sueltos» ${ }^{16}$.

En los casos de Granada y Cádiz, solo tenemos referencias indirectas que apuntan a la existencia de sendas congregaciones de ciegos en ambas ciudades. Por lo que respecta a Granada, en 1809 «Antonio Mas, ciego y vecino de Granada, y en nombre de los demás ciegos de dicha ciudad», presentó una solicitud para que se les permitiera vender papeles impresos por las calles, «como generalmente se practica en los pueblos del reino» ${ }^{17}$. Aunque este documento no hace referencia a ninguna hermandad de ciegos, el hecho de que Antonio Mas se presentara como representante de todos los ciegos de Granada, y de que el tema tratado fuera la venta de pliegos sueltos, reclamada por muchas de las corporaciones del resto de España, sugiere la posibilidad de que los ciegos granadinos se hubieran asociado también. En cuanto a Cádiz, de nuevo solo podemos aportar indicios: en 1811 se inició una

16. ARCG, caja 8585 .

17. AHN, Estado, 3082, Expediente 25.

Ediciones Universidad de Salamanca / @®@@ Stud. his., H. ${ }^{a}$ mod., 43, n. 1 (2021), pp. 293-322 
JUAN GOMIS Y EVA ROMERO

LAS HERMANDADES DE CIEGOS ORACIONEROS EN LA ESPAÑA MODERNA:

ENTRE LA POBREZA Y EL PRIVILEGIO

investigación en la isla de León para hallar al autor de una relación de sucesos falsa ${ }^{18}$. Las pesquisas condujeron a Juan Gilarte, «ciego, sordo y quebrado de ambas ingles», que había vendido la falsa relación por las calles de la isla de León. Entre las diversas preguntas incluidas en el interrogatorio al que fue sometido Gilarte, nos interesa destacar la última: «dónde existe el capataz de los ciegos, si este los abona a todos y cómo se llama». El fiscal se interesaba así por la autoridad de la corporación de la que presumía era miembro Gilarte. La respuesta de este confirmó sus sospechas: «que el capataz existe en esta de Cádiz, su nombre Juan Cerezo; que dicho capataz no abona a nadie, máxime desde la libertad de imprenta, y que el declarante no es del gremio de los de Cádiz». Tenemos una segunda fuente alusiva a esta congregación gaditana: una nota del semanario La Ilustración Católica ofrece datos históricos muy precisos sobre ella, también relativos a la venta de impresos. Al parecer, en 1756 la hermandad de ciegos de Cádiz incoó un pleito contra un librero esgrimiendo un privilegio, ganado un año antes, «concediéndoles el privilegio de vender estos papeles» ${ }^{19}$. Estos dos testimonios apuntan, pues, a la existencia de una cofradía (Gilarte habla de gremio) de ciegos establecida por entonces en Cádiz, pero, como en el caso de Burgos, y en general en el de estas cofradías que apenas asoman en la documentación, se precisan nuevas fuentes que permitan confirmar estos indicios.

En cualquier caso, lo que parece probado es que existió en la España moderna una tupida red de hermandades de ciegos, cuyo asociacionismo tuvo como fin el auxilio y sostenimiento de sus miembros, especialmente expuestos a la miseria y la indigencia. Uno de los medios esenciales para alcanzar tal fin era la obtención de ingresos, lo que impulsó la transformación de estas hermandades en corporaciones profesionales detentadoras de un oficio. En las páginas que siguen se analizará este proceso de profesionalización.

\section{EL REZO DE ORACIONES, UN OFICIO DE CIEGOS}

\subsection{La consecución del monopolio}

Dos fueron los oficios que las hermandades de ciegos controlaron de modo gremial: el rezo de oraciones y la venta de impresos. Ello fue posible gracias al apoyo que recibieron del Estado, que les concedió el monopolio sobre ambas actividades. Esta concesión no se produjo de modo simultáneo: el rezo de oraciones antecedió al comercio de papeles como oficio reconocido de los ciegos, y tuvo un recorrido mucho más largo. Fue, de hecho, como trataremos de demostrar en estas páginas, la actividad tradicional de los ciegos, llamados por ello con frecuencia en España

18. AHN, Diversos-Colecciones, 138, n. $^{\circ} 5$.

19. La Ilustración Católica, Año II, n. ${ }^{\circ}$ 40, p. 147.

Ediciones Universidad de Salamanca / @®@@ Stud. his., H. ${ }^{a}$ mod., 43, n. 1 (2021), pp. 293-322 
ciegos oracioneros o rezadores. A esta profesión se le añadiría, tardíamente y solo para las hermandades de determinadas ciudades, la venta de impresos.

Las hermandades de Valencia y Barcelona fueron, también en este aspecto, las pioneras. Ambas protagonizaron a lo largo del siglo XV una estrategia de apropiación de una actividad, el rezo de oraciones, tradicionalmente asociada a la mendicidad. De hecho, en las ordenanzas fundacionales de una y otra se menciona el limosneo como práctica habitual de los ciegos: los capítulos de la cofradía valenciana citan en varias ocasiones las «almoynes que Deus los donara et la bona gent», mientras que en Barcelona los ciegos son desde el inicio calificados como «mendicantes cecos». Los cofrades asociados se dedicaban pues, como tantos otros, a la búsqueda de limosnas por las calles, ofreciendo a cambio oraciones que les serían encomendadas por sus benefactores. Sin embargo, una vez ambas hermandades estuvieron consolidadas, iniciaron su evolución hacia corporaciones profesionales, cuya actividad sería el rezo de oraciones. En esta evolución, los ciegos contaron con el respaldo de las autoridades civiles y religiosas.

En otro trabajo hemos dado cuenta de los sucesivos pasos que dio la hermandad de la Vera Creu en pos de este objetivo (Gomis, 2010). Un privilegio dado por Fernando II en 1479 ordenó que todo aquel que se dedicara a «decir oraciones» por la ciudad pagara un dinero semanal a la congregación "para su sostenimiento». De este modo, se evitó que todo ciego pudiera servirse del rezo y recitación de oraciones como medio de sustento de forma particular, so pena de ser denunciado y sancionado con el pago de la correspondiente multa. Por tanto, este privilegio otorgado por Fernando II concedió a la cofradía de la Vera Creu el control de una actividad que tradicionalmente había sido libre y abierta como era el rezo de oraciones. Este fue el logro principal. A partir de aquí, la hermandad contó con la sanción real para exhibir como privativa la actividad del rezo, y reclamó por tanto el derecho a regularla a conveniencia. Los cofrades parecían ser conscientes de ello cuando, en el último capítulo aprobado por Fernando II, solicitaban poder «ordenar, mudar y mejorar y ajustar los capítulos y ordenanzas, para aumento y beneficio de la dicha cofradía» ${ }^{20}$.

El 26 de marzo de 1493, una deliberación de los jurados de la ciudad añadió, a petición de la cofradía de la Vera Creu, una nueva restricción para ejercer la actividad del $\mathrm{rezo}^{21}$. En este caso, se prohibió «decir oraciones» a todo aquel que no fuera «privado de la vista, de pies y manos, y que no pueden trabajar». La pena por contravenir esta orden era una multa de 30 sueldos y el destierro de la ciudad y sus arrabales, castigo que podía ser ejecutado por denuncia del síndico de Valencia y

20. AMV. MC A-41, f. 283r-285v. AMV. MC A-41, f. 283v-284r.

21. Copia traducida al castellano del documento en AHN, Consejos, leg. 22655, exp. 1, fols. $74-75$.

Ediciones Universidad de Salamanca / @®@@ Stud. his., H. ${ }^{a}$ mod., 43, n. 1 (2021), pp. 293-322 
JUAN GOMIS Y EVA ROMERO

LAS HERMANDADES DE CIEGOS ORACIONEROS EN LA ESPAÑA MODERNA:

ENTRE LA POBREZA Y EL PRIVILEGIO

de los mayorales de la hermandad de ciegos. Ésta, además, recibiría un tercio de la cantidad recaudada, siendo las dos partes restantes repartidas entre el municipio y el denunciante. A partir de este momento, la actividad del rezo de oraciones por parte de los no cofrades (que debían pagar una cuota semanal, como hemos visto) quedó limitada a toda persona que tuviera algún tipo de discapacidad y que se ganase la vida de este modo.

Finalmente, en 1502 la hermandad de la Vera Creu cerró definitivamente su cerco sobre la actividad del rezo. Presentó para ello nuevos capítulos a la reina Juana $\mathrm{I}^{22}$. Según afirmaban los mayorales, el motivo para reformar las ordenanzas era un problema ocasionado, paradójicamente, por el privilegio otorgado previamente por Fernando II. Dado que los capítulos aprobados por este permitían el rezo a los no cofrades a cambio de un dinero semanal, el gobierno de la cofradía observaba con alarma cómo muchos hermanos estaban abandonando la congregación, pues preferían pagar esa cantidad que las cuotas asignadas a cada cofrade, que ascendían al doble. Fuera este problema real o simulado, les sirvió como excusa para proponer el control absoluto sobre la actividad del rezo: toda persona «ciega o débil» que viviera de decir oraciones debía ingresar obligatoriamente en la hermandad, el pago de la cuota semanal de dos dineros se convertía en inexcusable para ejercer el rezo, y el cofrade moroso debía abandonar la actividad durante un mes por cada impago. La hermandad aprovechó para que la reina ratificara la decisión del gobierno municipal de prohibir el rezo de oraciones a las «personas sanas y robustas», e introdujo la petición de que se expulsara a los forasteros mendicantes que deambulaban por la ciudad pidiendo limosna. Juana I accedió a todas las demandas de los ciegos, que de este modo culminaron la conversión del rezo de oraciones en una profesión exclusiva. En apenas 20 años habían conseguido eliminar la competencia de los rezadores foráneos, los sanos y los no cofrades. Y, en este proceso, contaron en todo momento con el apoyo de las autoridades, tanto reales como municipales.

La hermandad de Barcelona siguió la misma senda que la cofradía de la Vera Creu. De hecho, la antecedió en la apropiación del rezo y pudo incluso constituir la inspiración de la valenciana: así parecen sugerirlo los capítulos aprobados por Fernando II, donde se menciona repetidamente a la cofradía del Sant Esperit como el modelo que seguían los ciegos valencianos para presentar sus demandas («segons que a la confraria dels pobres hòmens cechs e miserables persones de la ciutat de Barcelona qui van dient oracions e prenen caritats de aquelles és acostumat per privilegis e ordinacions de aquella», "atorgant-los totes aquelles prerrogatives e libertats que per los dits privilegis als de la ciutat de Barcelona és atorgat») ${ }^{23}$. Sin embargo, la falta de documentación primaria nos impide hacer un seguimiento tan detallado

22. Archivo del Reino de Valencia (ARV), Real Cancillería, n. ${ }^{\circ} 318$, fols. 46v-50.

23. AMV. MC A-41, f. 284r y 284v.

Ediciones Universidad de Salamanca / @®@@ Stud. his., H. ${ }^{a}$ mod., 43, n. 1 (2021), pp. 293-322 
JUAN GOMIS Y EVA ROMERO

LAS HERMANDADES DE CIEGOS ORACIONEROS EN LA ESPAÑA MODERNA:

ENTRE LA POBREZA Y EL PRIVILEGIO

como en el caso valenciano sobre los pasos seguidos por la hermandad de Barcelona para hacerse con el control del rezo: según evoca vagamente un memorial de 1815, ya las hermandades de San Andrés y San Martín, antes de ser unificadas por María de Aragón en 1433, tenían privilegio para «ganar el sustento que necesitaban y sus familias mediante el canto y el rezo de salmos y oraciones, con exclusión de otros» ${ }^{24}$. El mismo documento afirma que el gobierno de la ciudad reconoció más tarde esta prerrogativa: a través de un privilegio de 20 de abril de 1526 «fue ratificada la preeminencia de sus individuos acerca del rezo de salmos y oraciones dentro de la propia población, en su término y territorio».

Así pues, las hermandades de Valencia y Barcelona fueron las primeras en recibir del poder civil el monopolio sobre la actividad del rezo, reconvertida a partir de entonces en el oficio propio de los ciegos.

Con el ejemplo de las cofradías levantinas bien presente, las congregaciones que se fundaron durante el siglo XVI tuvieron el oficio del rezo como uno de sus objetivos principales desde el inicio. De hecho, no es inverosímil pensar que alcanzar la condición gremial fuera un estímulo de peso para impulsar el asociacionismo de los ciegos. Más allá de los beneficios mutualistas y religiosos, la fundación de una hermandad conllevaba la posibilidad de elevar el limosneo a la condición de profesión. El apoyo del Estado fue, de nuevo, clave para que las cofradías creadas en el siglo XVI obtuvieran el monopolio sobre el rezo de oraciones. Como en el caso de la hermandad de la Vera Creu, los ciegos consiguieron este privilegio de parte de las autoridades civiles a través de la aprobación de sus ordenanzas y de sucesivos capítulos referidos a la profesión. El caso de la cofradía de la Transfiguración de Zaragoza es bien claro al respecto: en sus primeras ordenanzas, de 1537, ya entendían como privativa la actividad del rezo. Por un lado, establecían la discapacidad como requisito para dedicarse a la profesión: «que ninguna persona de cualquier ley, estado o condición pueda ganar dineros a decir oraciones por las casas, si no que tenga impedimento de enfermedad a conocimiento de los dichos mayordomos». La multa fijada por contravenir esta norma era de dos sueldos por cada infracción. Por otro lado, se ordenaba el ingreso en la hermandad a todo impedido que quisiera ejercer el oficio: «que cualquier persona que andara diciendo oraciones por las casas y ganara dineros a decirlas, sea tenido a entrar cofrade en la dicha confradía y pagar por la entrada cinco sueldos al común de la confradía» ${ }^{25}$. En este caso, se fijaba en dos dineros semanales la cantidad a pagar para todo rezador que no aceptara ingresar en la hermandad.

Lo interesante de este caso es comprobar cómo el gobierno municipal de Zaragoza, responsable de la aprobación de estas ordenanzas fundacionales, aceptó

24. Archivo Histórico de Barcelona (AHB), Gremis, 53-73.

25. AMZ, Libro de Actas, 1537.

Ediciones Universidad de Salamanca / @®@@ Stud. his., H. ${ }^{a}$ mod., 43, n. 1 (2021), pp. 293-322 
JUAN GOMIS Y EVA ROMERO

LAS HERMANDADES DE CIEGOS ORACIONEROS EN LA ESPAÑA MODERNA:

ENTRE LA POBREZA Y EL PRIVILEGIO

y refrendó de entrada el monopolio que los ciegos se adjudicaron sobre el rezo de oraciones. A partir de entonces, nadie que no fuera miembro de la hermandad podría buscar limosnas a cambio de oraciones por las calles de la ciudad. Lo que a las hermandades de Valencia y Barcelona les costó más de un siglo obtener, a la zaragozana se le otorgó desde su mismo nacimiento. Del mismo modo, el resto de congregaciones de ciegos fundadas en el siglo XVI obtuvieron, si no desde su misma creación, al poco tiempo, el monopolio sobre la profesión del rezo. En la documentación manejada este es, en efecto, el oficio atribuido a los ciegos para la totalidad de las hermandades conocidas en España.

\subsection{La regulación del oficio}

Al igual que cualquier otra actividad profesional, las cofradías regularon minuciosamente el rezo de oraciones en sus ordenanzas. Gracias a ello podemos aproximarnos hoy al desempeño rezador de los ciegos. Las hermandades estipulaban un período de aprendizaje que variaba de un año y medio a tres años (Zaragoza y Valencia, respectivamente ${ }^{26}$ ), con dos lecciones diarias impartidas por un maestro oracionero. Conocemos numerosos contratos que estipulaban las condiciones del aprendizaje y los deberes de maestro y discípulo (Cátedra: 2001, 136-145; Álvarez: 2001; Gomis: 2019, 53). Además de las oraciones, en ocasiones estos contratos incluían la enseñanza del canto y del tañido de instrumentos musicales como la guitarra o el violín. En el caso de la hermandad de Valencia, incluso se especificaban las oraciones que el aspirante a rezador debía memorizar, las cuales estaban dictadas en el catálogo de cien plegarias incluido en las ordenanzas ${ }^{27}$. La existencia de este catálogo nos da una idea de la cantidad de oraciones que nutrían el repertorio del ciego rezador, cuya profesionalidad se basaba, antes que nada, en su capacidad para satisfacer cualquier requerimiento pío que sus devotos clientes le hicieran. Esta maestría en el oficio exigida por las ordenanzas arroja nueva luz a tantas representaciones literarias de los Siglos de Oro que muestran al ciego oracionero anunciando largas letanías listas para ser entonadas (la Farsa del molinero de Diego Sánchez de Badajoz, el Entremés de un ciego y un mozo y un pobre muy gracioso de Joan de Timoneda, o Pedro de Urdemalas de Miguel de Cervantes). Es inevitable que venga a la mente el primer amo de Lázaro de Tormes y su dominio oracionero: «ciento y tantas oraciones sabía de coro [...] Decía saber oraciones para muchos y diversos efectos: para mujeres que no parían, para las que estaban de parto, para las que eran malcasadas, que sus

26. AMZ, Libro de Actas, 1737. En las ordenanzas de 1788 se reducía el período de aprendizaje a un año (Archivo Histórico Provincial de Zaragoza-AHPZ-, Sección J.910, 18). Sobre las ordenanzas de la hermandad valenciana, Archivo de Protocolos Notariales del Real Colegio Seminario de Corpus Christi de Valencia (APCCV), n. ${ }^{\circ} 13134$, fols. 130v-131r.

27. APCCV, n. ${ }^{\circ} 13134$, fols. 131v-132v.

Ediciones Universidad de Salamanca / 요 Stud. his., H. ${ }^{a}$ mod., 43, n. 1 (2021), pp. 293-322 
JUAN GOMIS Y EVA ROMERO

LAS HERMANDADES DE CIEGOS ORACIONEROS EN LA ESPAÑA MODERNA:

ENTRE LA POBREZA Y EL PRIVILEGIO

maridos las quisiesen bien» (Rico, 2005: 25-26). A tenor de lo que muestran las fuentes citadas, estas imágenes no tenían nada de hiperbólico.

El aprendizaje del rezo era un proceso clave para las hermandades, tanto porque una correcta formación profesional resultaba esencial para preservar la profesionalidad de los cofrades, como porque constituía una fuente de ingresos extra para los maestros. Por lo tanto, estaba férreamente controlado por los prohombres de la congregación. Así, las hermandades prohibían que ningún cofrade asumiera aprendices sin que sus clavarios y mayorales dieran su visto bueno: la de Zaragoza establecía que ningún «aprendiz que, siendo ciego, quisiera entrar a aprender oraciones» comenzara su aprendizaje sin permiso del clavario (que debía ser «con el primero que hablare»), y que «ninguno sea osado a tomarlo hasta que este [el maestro] sea designado» 28 , y la de Barcelona ordenaba que «ningún cofrade, ciego o estropeado, no pueda mostrar de decir oraciones a ninguna otra persona que sea ciega o estropeada a escondidas, sin que sea manifestado a los prohombres y mayorales de la cofradía» ${ }^{29}$.

Los años de aprendizaje debían ponerse a prueba para que el ciego demostrara ser merecedor del estatus de oracionero. Para ello, las hermandades organizaban un examen de acceso al oficio, que corría a cargo de los cofrades «más hábiles y suficientes de oraciones» ${ }^{30}$. Era el último obstáculo que el aspirante debía superar para acceder al oficio y, como en el resto de aspectos relativos a la regulación de la profesión, las hermandades se mostraban férreas al exigir su cumplimiento: así, en 1542 la cofradía de Valencia denunció al company Francisco Benvengut, maestro oracionero, después de sorprender a uno de sus aprendices ejerciendo el rezo antes de haber sido examinado 31 .

Como el aprendizaje, la propia actividad oracionera estaba sometida a reglamentación. La profesionalidad de los ciegos debía ser salvaguardada a toda costa: las ordenanzas prohibían explícitamente que el rezador entonara una plegaria distinta a la solicitada por el cliente, o que no la completara una vez este se había alejado ${ }^{32}$. Asimismo, se exigía de los oracioneros un comportamiento irreprochable, vetando el canto de «cosas profanas o escandalosas» ${ }^{33}$, la exclamación de palabras deshonestas, el juramento en nombre de Dios, de la Virgen o de los santos, o cualquier acción indecente. Algunas hermandades trataban incluso de velar por inculcar este buen

28. AMZ, Libro de Actas, 1549.

29. AHB, Gremis, 53-73.

30. AHB, Gremis, 53-75.

31. ARV, Procesos criminales, caja 4412, expediente 272.

32. Tal y como hacía el amo de Lázaro, o como denunciaba Carlos García en La desordenada codicia de los bienes ajenos: «el ciego hurta de cada oración que dice la mitad» (García: 1998, 114).

33. APCCV, n. ${ }^{\circ} 13134$, fol. $137 \mathrm{v}$. 
comportamiento a la gente común: la de Sevilla, por ejemplo, exhortaba a sus cofrades a invocar en alta voz el nombre de Jesús cada vez que oyeran a alguien «votar y jurar a Dios nuestro Señor y a su gloriosa Madre y a los Santos, [...] con grande peligro para sus almas» ${ }^{34}$. En el caso de apostarse a la puerta de una iglesia para ofrecer sus plegarias, el ciego debía evitar levantar la voz o mantener conversaciones con otros cofrades que importunaran la devoción de los fieles. Incluso el propio atuendo de los oracioneros era objeto de atención en los capítulos, que insistían en que el vestido y calzado de cada asociado fuera, en la medida de sus posibilidades, de «la más posible decencia y honestidad, que edifique a los de vista» ${ }^{35}$.

Las ordenanzas revelan la existencia de una clientela fija, estable, asignada a un oracionero, que tenía encomendado el rezo regular de determinadas plegarias. Las fuentes denominan «parroquianos» a estos fieles. El intrusismo entre los ciegos quedaba descartado, pues se prohibía tajantemente que un hermano rezara para el parroquiano de otro, a no ser que confirmara que este había sido despedido e informara puntualmente a la cofradía. El cumplimiento para con esta clientela fija quedaba asegurado incluso en el caso de que el rezador enfermara, pues las ordenanzas estipulaban que las oraciones encomendadas fueran repartidas por el clavario entre el resto de cofrades, quienes las asumirían hasta que el convaleciente se recuperara ${ }^{36}$.

Los tiempos y lugares para el ejercicio del rezo estaban, asimismo, regulados. Respecto al horario, las ordenanzas distinguían entre hombres y mujeres: mientras que los primeros no tenían limitación alguna, las rezadoras solo podían desempeñar el oficio por la noche, con la excepción de determinadas festividades. Respecto a la ocupación del espacio urbano por parte de los ciegos, las ordenanzas se limitaban a exhortar a los hermanos a respetar los lugares en los que cada cual acostumbraba a apostarse, y a evitar cualquier conflicto en caso de coincidir dos rezadores en un mismo sitio.

Finalmente, las ordenanzas se ocupaban también del precio que los rezadores podían pedir por sus plegarias. El objetivo era impedir que los ciegos compitieran entre sí rebajando sus honorarios. La hermandad de la Vera Creu estipulaba que un dinero era la cantidad mínima que un cofrade debía exigir por una oración recitada, que ascendía a dos en el caso de ser cantada y aun a más si la plegaria era «más larga de lo ordinario y regular» ${ }^{37}$.

34. AGAS, Justicia, Hermandades, Signatura 09817, Expediente 10.

35. APCCV, n. ${ }^{\circ} 13134$, fol. 138 r.

36. AMZ, Libro de Actas, 1602.

37. APCCV, n. ${ }^{\circ} 13134$, fol. 134 r. 
JUAN GOMIS Y EVA ROMERO

LAS HERMANDADES DE CIEGOS ORACIONEROS EN LA ESPAÑA MODERNA:

ENTRE LA POBREZA Y EL PRIVILEGIO

\section{LAS HERMANDADES DE CIEGOS Y EL PODER}

\subsection{Una profesión frente a la policía de pobres}

Así pues, una vez acaparada la actividad del rezo merced al apoyo brindado por las autoridades, las hermandades pusieron todo su empeño en regularla y dotarla así de una apariencia de profesionalidad. El propio hecho de normativizar por escrito la tarea oracionera, incorporando para ello capítulos específicos en sus ordenanzas, era en sí mismo un acto destinado a reconocer el rezo como una actividad profesional, semejante a la del resto de oficios. Cualquier falta o incorrección de los ciegos al ejercer el rezo suponía un menoscabo al estatus gremial defendido por la cofradía: tal y como reconocía la hermandad sevillana, sus ordenanzas debían procurar extirpar «algunos defectos y excesos» en el rezo de plegarias, pues restaban el «crédito y opinión» que las gentes tenían de los oracioneros. La cofradía de Valencia declaraba su disposición a tomar cualquier medida que resultara «más conveniente para arrancar de raíz semejantes abusos, excesos y profanidades, que ceden en perjuicio de la edificación cristiana» ${ }^{38}$.

La consideración social de los ciegos y su actividad no era asunto menor. En un período de renovado ímpetu combativo contra la mendicidad en Europa, derivado de nuevas formas de caridad más selectivas y discriminatorias y de una tendencia hacia la secularización de la gestión asistencial (Grell y Cunnigham, 1997; Grell, Cunnigham y Arrizabalaga, 1999; Bolufer, 2002), marcar distancias con respecto a la masa de pobres, mendigos y vagabundos devino esencial para los oracioneros. En ningún caso podían dar por descontado un tratamiento distintivo, que les excluyera del escalafón más bajo y degradado de la población mendicante, constituido por los «falsos pobres», aquellos individuos que, según los tratadistas, rehuían voluntariamente el trabajo esgrimiendo sus achaques, o fingiéndolos directamente. Son numerosas y conocidas las referencias de textos literarios y tratados sobre la mendicidad del siglo XVI que asociaban los ciegos al mundo de la picaresca y la vagancia y alegaban su capacidad para ejercer un oficio. Luis Vives les consideraba aptos «para muchas faenas» como las letras, la música, determinados trabajos mecánicos (tornos, prensas, fuelles, cestería, hilado), afirmando que solo la pereza y la holgazanería les mantenía «mano sobre mano» (Vives, 1992: 162-163). En esto le seguían otros autores, como Alejo Venegas (Cátedra, 2002: 117) o Miguel Giginta, quien consideraba que un inmenso porcentaje de la población mendiga podía trabajar, incluyendo los «ciegos, cojos, tontos, niños, niñas y hasta el que tuviere una sola mano, y ninguna pierna» (Cavillac, 1979: 44). De ahí a considerar que los ciegos con sus plegarias no eran sino simples limosneros, vagabundos que

38. APCCV, n. ${ }^{\circ} 13134$, fols. $138 \mathrm{v}-139 \mathrm{r}$.

Ediciones Universidad de Salamanca / అ@@ Stud. his., H. ${ }^{a}$ mod., 43, n. 1 (2021), pp. 293-322 
JUAN GOMIS Y EVA ROMERO

LAS HERMANDADES DE CIEGOS ORACIONEROS EN LA ESPAÑA MODERNA:

ENTRE LA POBREZA Y EL PRIVILEGIO

rehuían el trabajo, no había más que un paso. De hecho, así parecía reconocerlo la legislación vigente, como la real cédula de Carlos I de 1540, principal disposición general castellana sobre el «socorro y recogimiento de pobres» del siglo XVI, que distinguió «la facultad de los ciegos para pedir limosna sin licencia alguna en los pueblos de su naturaleza o vecindad» ${ }^{39}$, o la posterior orden de Felipe II (1565), que admitía el derecho al limosneo de los ciegos, junto con lisiados y ancianos ${ }^{40}$. Estas disposiciones asumían que los ciegos eran mendicantes a los que debía guardarse el permiso para pedir limosnas en atención a su minusvalía. Vives y otros tratadistas, sin embargo, no aceptaban tal distinción, y contemplaban el rezo como una mera forma de pordioseo que apartaba a los ciegos de ocupaciones para las que eran totalmente capaces. Y esta idea era alimentada por los prejuicios sobre la codicia de los ciegos y sobre los pingües beneficios que las oraciones les proporcionaban, disuadiéndoles de dedicarse a cualquier otra actividad productiva pero menos lucrativa. En las Relaciones de la vida del escudero Marcos de Obregón, Vicente Espinel ponía en boca de su protagonista una alusión al apetecido negocio de las oraciones entre los desclasados:

Mas la gente que más bendiciones me echa es la que curo de la vista corporal, porque como todos o la mayor parte son pobres y necessitados, con la fuerça de cierta confección que yo sé hazer de atutia y cardenillo y otros simples, y con la gracia de mis manos, a cinco o seys veces que vienen a ellas los dexo con oficio, con que ganan la vida muy honradamente, alabando a Dios y a sus santos con muchas oraciones devotas, que aprenden sin poderlas leer ${ }^{41}$.

En la misma línea, pero enfatizando aún más la crueldad del acto, autores como Cristóbal Pérez de Herrera, en su tratado sobre pauperismo, o Mateo Luján, en la segunda parte del Guzmán, denunciaban casos en que padres menesterosos habían cegado a sus hijos "para que de esta manera queden con manera de vivir y renta de por vida» (Pérez de Herrera, 1975: 27; Luján, 1956: 623).

Es evidente que la consideración del rezo como una profesión digna de tal nombre estaba lejos de ser unánime, y que según estos y otros autores solo la pereza y la ganancia fácil proporcionada por las oraciones alejaban a los ciegos de una «auténtica» ocupación laboral. No es inverosímil, en consecuencia, que las hermandades de invidentes, una vez obtenido el monopolio del rezo de plegarias, trataran de dar a esta actividad los contornos propios de cualquier otro oficio gremial, con el fin de alcanzar un reconocimiento profesional que otras opiniones, en línea con los textos citados, les negaban. Que el rezo fuera considerado un trabajo digno, y

39. Novísima Recopilación de las Leyes de España, libro VII, título XXXIX, leyes I-XI.

40. Novísima Recopilación de las Leyes de España, libro VII, título XXXIX, ley XIV.

41. Espinel: 1999, relación primera, 2. 
JUAN GOMIS Y EVA ROMERO

LAS HERMANDADES DE CIEGOS ORACIONEROS EN LA ESPAÑA MODERNA:

ENTRE LA POBREZA Y EL PRIVILEGIO

no una forma más de pordioseo, representaba para los ciegos la oportunidad de alejarse del resto de pobres y, por tanto, mantener a raya las sucesivas y crecientes políticas asistenciales y de limitación de la mendicidad. Si bien las citadas cédulas de Carlos I y Felipe II reconocían su derecho a pedir limosnas y les resguardaban de las medidas contra los «falsos pobres», esta distinción no podía darse por segura. De hecho, conocemos sucesivos casos en los que, viéndose afectados por la «policía de pobres», los ciegos oracioneros tuvieron que escudarse en la dignidad de su oficio para salir del aprieto. Así, por ejemplo, cuando en 1674 la Congregación del Ave María comenzó a recoger mendigos de las calles de Madrid para su ingreso en el Hospital, la hermandad de Nuestra Señora de la Visitación se apresuró a solicitar la exención de sus asociados ante la iniciativa, esgrimiendo entre otras razones la distinción que les proporcionaba su condición «gremial»: argumentaban, así, que siempre habían tenido "gremio separado de los pobres mendicantes», que se mantenían «sin pedir, como los otros, de puerta en puerta, sino con lo que ganan de las oraciones que van a rezar a diferentes casas de personas», y que por tanto «no eran mendicantes, vagabundos y mal entretenidos, molestos y perjudiciales» (Espejo: 1925, 221-223). Los ciegos remarcaban, pues, la distancia que les separaba de los pordioseros, cimentando el argumento en su dignidad profesional. Del mismo modo, cuando en 1774, tras la publicación en Murcia de un bando prohibiendo el limosneo, el corregidor comenzó a hostigar a los ciegos de la ciudad para que cesaran en sus actividades ambulantes, la hermandad de Nuestra Señora de la Presentación replicó aludiendo a la «inmemorial posesión y costumbre» de su oficio, que permitía a sus miembros subsistir «sin necesidad de recurrir a mendigar y pedir limosna de puerta en puerta» ${ }^{42}$. En 1804, ante la orden de recogimiento en la Casa de la Caridad de Barcelona, la cofradía del Sant Esperit alegó que sus asociados no podían ser confundidos con mendigos, pues vivían «con el producto del trabajo cristiano y religioso de cantar y rezar los salmos penitenciales» ${ }^{43}$. Con cierto atrevimiento, aun reconociendo «las benéficas intenciones de Su Majestad», los ciegos de Barcelona apelaban directamente al monarca asegurando que «no pudo caber en su Real Ánimo una providencia por la que sujetase a los individuos del Gremio de Sancti Spiritus a la suerte de los que mendigan». Elevar a la dignidad de oficio la actividad del rezo fue, pues, un objetivo perseguido con ahínco por los oracioneros, cuyo temor a ser confundidos con el resto de la población indigente respondía a una realidad que fue ejemplarmente expresada por el corregidor de Madrid en su respuesta a las quejas de los ciegos por el citado recogimiento de 1674: «dicen se ponen en las puertas de las iglesias a rezar por los que les dan limosna: no hallo más diferencia en estos y los demás pobres mendicantes» (Espejo, 1925: 223).

42. AHN, Consejos, leg. 1231, exp. 23, fols. 7-8.

43. AHB, Gremios 53, caja 73.

Ediciones Universidad de Salamanca / @®@@ Stud. his., H. ${ }^{a}$ mod., 43, n. 1 (2021), pp. 293-322 
JUAN GOMIS Y EVA ROMERO

LAS HERMANDADES DE CIEGOS ORACIONEROS EN LA ESPAÑA MODERNA:

ENTRE LA POBREZA Y EL PRIVILEGIO

\subsection{Los privilegios otorgados a las hermandades: ‘̇algo más que política asistencial?}

El asociacionismo de los ciegos, por tanto, encarnado en la proliferación de hermandades que desde el siglo XIV se dio en las principales ciudades del territorio hispánico, les proporcionó asistencia mutua, fortaleza corporativa para interactuar con las autoridades civiles, un medio de vida como el rezo de oraciones, y protección frente a las medidas contra los menesterosos. Estas ventajas permiten explicar la longevidad de estas cofradías, cuya extinción solo acontecería por imposición del naciente Estado liberal a mediados del siglo XIX.

Siendo evidentes los beneficios del corporativismo para los ciegos, cabría preguntarse, en sentido inverso, qué finalidades impulsaron al poder político a apoyar constante y decididamente a sus hermandades a lo largo de los siglos, en sus inicios fundacionales, en su desarrollo organizativo (aprobación de las sucesivas ordenanzas), y en su actividad profesional (concesión de los monopolios sobre el rezo de oraciones primero, y sobre la venta de pliegos sueltos en un segundo momento, en el siglo XVIIII pero solo para algunas cofradías). Uno de sus objetivos más obvios fue, sin duda, alentar la autonomía de un colectivo que, a pesar de su especial vulnerabilidad frente a las adversidades de la vida, demostró sin embargo una notable capacidad organizativa. Apoyando la creación de sus hermandades, las autoridades fomentaban unas redes de ayuda mutua eficaces, que contribuían a aliviar los pesares de los ciegos. Otorgándoles el privilegio sobre determinadas actividades, les proporcionaban un medio para ganarse el pan y alejarse de la indigencia. Se trataba, pues, de acciones que seguían la lógica asistencial impulsada progresivamente por el Estado moderno, y que facilitaban al poder político una solución eficaz y simple para un colectivo vulnerable que, de otro modo, engrosaría el conjunto de pobres y mendigos que inquietaban a la administración en su lucha contra el pauperismo.

Sin embargo, más allá de esta obvia prioridad, es posible detectar otro objetivo menos evidente en el trato dispensado por las autoridades civiles a las cofradías de ciegos. Se trata de una hipótesis que parte de la interpretación que Jean-François Botrel hizo en su estudio pionero sobre el monopolio que la monarquía borbónica dio a la hermandad madrileña sobre la venta callejera de impresos (Botrel, 1973). Este privilegio fue entendido por Botrel no solo como una muestra de beneficencia por parte del Estado ilustrado en atención a la minusvalía de los cofrades, sino como una medida que perseguía también aumentar el control de las autoridades sobre la difusión de los pliegos sueltos, un tipo de material especialmente escurridizo frente la censura. Al reducir el número de vendedores autorizados a los miembros de la hermandad se limitaban los circuitos de diseminación de los impresos y se facilitaba la identificación del responsable de la difusión, la impresión y, en última instancia, la autoría de cualquier texto prohibido. Así, durante los años de vigencia del monopolio, los ciegos devinieron, en palabras de Botrel, «colaboradores objetivos del poder». Estudios recientes han visto en la concesión de monopolios similares

Ediciones Universidad de Salamanca / 요 Stud. his., H. ${ }^{a}$ mod., 43, n. 1 (2021), pp. 293-322 
JUAN GOMIS Y EVA ROMERO

LAS HERMANDADES DE CIEGOS ORACIONEROS EN LA ESPAÑA MODERNA:

ENTRE LA POBREZA Y EL PRIVILEGIO

a otras hermandades de ciegos una estrategia de control sobre la circulación de los impresos de mayor alcance que la apuntada por Botrel para Madrid (Gomis, 2015).

La cuestión que nos gustaría plantear aquí es si, en la línea sugerida por Botrel y otros autores en referencia a los privilegios sobre la venta de pliegos sueltos, podría interpretarse la concesión del monopolio sobre el rezo a las hermandades de ciegos en un sentido similar, como parte de una estrategia de control sobre la difusión de las oraciones por parte de las autoridades civiles y religiosas. El riesgo de diseminación de ideas supersticiosas, heterodoxas e incluso heréticas que podía esconderse tras una práctica de apariencia tan pía como el rezo era conocido en los siglos modernos. Tal y como ha demostrado María Taussiet en numerosos trabajos (2004 y 2007), el recurso a las oraciones y otros elementos de la tradición cristiana era común en las prácticas de brujería y hechicería. Magia y religión, de hecho, compartían fronteras difusas, en absoluto claramente delimitadas. Así, en las prácticas de inspiración diabólica diseccionadas por Pedro de Ciruelo en su influyente obra Reprobación de las supersticiones y hechicerias (1538), las plegarias desviadas desempeñaban un papel esencial: tanto en la invocación demoníaca propia la nigromancia, en la predicción del futuro de la adivinación, en la curación de enfermedades del ensalmo o en la consecución de cualquier deseo prometida por la hechicería. De hecho, Ciruelo se ocupaba específicamente de las oraciones en un capítulo sobre «en cuántas maneras pueden los hombres pecar en las oraciones que hacen a Dios y a los santos» (1551: 53). Del mismo modo, como es bien conocido, la Inquisición española incluyó en sus índices de libros prohibidos de 1559 y 1583 once oraciones que consideraba vinculadas a creencias supersticiosas (Londoño, 2019). Las denuncias que diversos sínodos obispales del siglo XVI lanzaron contra las plegarias supersticiosas demuestran, asimismo, la preocupación de la jerarquía eclesiástica por el asunto ${ }^{44}$. En este sentido, es interesante la prohibición que en 1572 decretó el arzobispado de Granada en sus constituciones sinodales contra las oraciones desviadas, pues junto a las nóminas, adivinaciones, saludadores, ensalmadores y santiguaderas citó las «oraciones de ciegos». De este modo, el sínodo equiparaba los ciegos a otros comunes practicantes de hechicerías, y de hecho así lo declaró explícitamente al afirmar que «las personas que más usan de estas cosas son saludadores, ensalmadores, santiguaderas y ciegos que rezan por las puertas y calles» ${ }^{45}$.

Los ciegos participaron con frecuencia, en efecto, en este tipo de prácticas supersticiosas, tal y como demuestran los numerosos procesos inquisitoriales en

44. Agradecemos a Emilio Callado Estela sus lúcidas orientaciones al respecto.

45. Constituciones synodales del arcobispado de Granada. Hechas por el Ilustrissimo Reuerendissimo Señor Don Pedro Guerrero Arçobispo de la Sancta Yglesia de Granada. En el sancto Synodo qye su Señoria Reuerendissima celebro à quatorze días del mes de Octubre del año M.D.LXXII (Granada: Hugo de Mena, 1573), fol. 99.

Ediciones Universidad de Salamanca / @®@@ Stud. his., H. ${ }^{a}$ mod., 43, n. 1 (2021), pp. 293-322 
JUAN GOMIS Y EVA ROMERO

LAS HERMANDADES DE CIEGOS ORACIONEROS EN LA ESPAÑA MODERNA:

ENTRE LA POBREZA Y EL PRIVILEGIO

que se vieron inmersos: las «palabras escandalosas» que gritaban por las calles llevaron ante el tribunal a los ciegos Alonso de Casar en 1532, Gabriel López en 1570 y Alonso de Valcázar en 1618, este último acusado de mezclar estas expresiones indecentes con las oraciones que cantaba ${ }^{46}$. Juan García fue condenado en 1654 a un año de destierro por gritar por la calle una y otra vez "iglorioso san Agustín, niego el matrimonio de Dios!» ${ }^{47}$. En 1717, Cristóbal Martínez, apodado «El ciego de los pinos», fue sometido a un proceso de fe por su fama de hallador de objetos perdidos mediante oraciones, y en 1776 Jerónimo Herrero fue condenado a prisión y embargo de bienes por «supersticioso, adivino demoníaco y sospechoso de herejía» ${ }^{48}$.

Aparentemente, estos casos parecen refutar la hipótesis planteada, al presentar a los ciegos como difusores de plegarias heterodoxas y escandalosas. Sin embargo, más bien al contrario, denuncias como las descritas, dirigidas contra individuos ciegos que ejercían libremente el rezo, subrayan precisamente la oportunidad que brindaban las hermandades para erradicar esas prácticas desviadas y censuradas. Al someter el oficio a una estricta regulación que añadía incluso, en ocasiones, el número y título de las oraciones que los cofrades estaban autorizados a rezar, las corporaciones ejercían un indudable papel de control en colaboración con las autoridades civiles y religiosas. El rezo de plegarias podía seguir desarrollándose en las calles siempre y cuando estuviera supervisado. El recurso a las hermandades de ciegos parece seguir la misma lógica que medidas como la adoptada por el citado sínodo de Granada de 1572 que, si bien por un lado prohibió las oraciones supersticiosas de saludadores, ensalmadores, santiguaderas y ciegos, por otro se avino a permitirlas si se sometían a su control, ordenando que todos estos rezadores acudieran al obispado para que fuesen examinados «y para que se les avise de las oraciones y ensalmos que deben usar y de los que no, so pena de que de aquí en adelante curare, ensalmare o rezare sin la dicha licencia se procederá contra ellos conforme a derecho» ${ }^{49}$. La misma postura posibilista adoptó el sínodo del obispado de Segovia de 1586, dictaminando «que ninguna persona traiga nóminas, ni reliquias, ni otras cosas con pretexto de devoción, sin que primero sea examinada por nos, o por quien para ello tuviere nuestra

46. AHN, Inquisición, 200, Exp. 3; 205, Exp. 24; 211, Exp. 8.

47. AHN, Inquisición, 1674, Exp. 5.

48. AHN, Inquisición, 3733, Exp. 185; 3726, Exp. 230. En su Tratado de remedio de pobres, Miguel Giginta aludía asimismo a las «alegrías» teológicas que los ciegos se permitían al rezar las oraciones: «qué me diréis de una cosa importante, poco advertida de los ciegos, que ellos mismos se ordenan las oraciones que quieren, con las cuales prometen mil seguranzas en el cielo y en la tierra para sacar dinero, metiéndose por la Encarnación y Trinidad más largamente de lo que muchos teólogos osarían» (Tratado de remedio de pobres, edición de Félix Santolaria, Barcelona, Ariel, 2000, p. 73).

49. Constituciones synodales del arcobispado de Granada, fol. 99.

Ediciones Universidad de Salamanca / @®@@ Stud. his., H. ${ }^{a}$ mod., 43, n. 1 (2021), pp. 293-322 
JUAN GOMIS Y EVA ROMERO

LAS HERMANDADES DE CIEGOS ORACIONEROS EN LA ESPAÑA MODERNA:

ENTRE LA POBREZA Y EL PRIVILEGIO

comisión, ni cure con ensalmos ni bendiciones sin que primero sean examinadas y aprobadas las palabras que dice ${ }^{50}$.

Las hermandades de ciegos, plegadas al poder religioso y civil que aprobaba sus ordenanzas y les otorgaba privilegios, se constituyeron de este modo en instrumento de mediación y control del desempeño del rezo, encauzado dentro de los límites establecidos por la ortodoxia. Aunque solo se trata de una hipótesis basada en los indicios apuntados, no resulta inverosímil plantear que, como ocurriría en el siglo XVIII con el monopolio sobre la venta de pliegos sueltos, el monopolio sobre la práctica oracionera no solo respondió, pues, a un impulso asistencial por parte del Estado y la Iglesia, sino que albergó otras finalidades vinculadas al aparato censor y al control de las conciencias. Podríamos decir, desarrollando la idea de Botrel, que el «colaboracionismo» de los ciegos asociados asumió distintas formas y se desplegó durante varios siglos. Cuando en 1834, en su conocido «Informe sobre las ordenanzas de la hermandad de los ciegos de Madrid» (1864) que pondría el punto y final a la existencia de la cofradía madrileña, Salustiano de Olózaga criticó acerbamente la «decidida protección» que el absolutismo había dispensado a los ciegos, no podía sospechar que esa «secreta relación» no se limitaba, ni mucho menos, al período fernandino.

\section{CONCLUSIONES}

Aunque la fundación de hermandades de ciegos fue una práctica común en la Europa bajomedieval y de la temprana Edad Moderna, en el territorio hispánico el fenómeno destacó tanto por su proliferación (solo comparable a la acaecida en las ciudades italianas) como por su perdurabilidad a través de los siglos, interrumpida ya avanzado el siglo XIX por el despertar del Estado liberal. Se podría afirmar que el fenómeno adquirió en la España moderna unos perfiles propios y característicos.

En este trabajo se han presentado evidencias sobre la existencia de cofradías de ciegos en Valencia, Barcelona, Zaragoza, Madrid, Burgos, Sevilla, Córdoba, Málaga, Granada, Cádiz y Murcia. No es descartable que existieran también en otras ciudades. El estudio de su fundación y evolución permite dar a conocer las estrategias de ayuda mutua desplegadas por esta comunidad especialmente desvalida y expuesta, que cimentó sobre el asociacionismo entre sus miembros un andamiaje de autoprotección frente a la enfermedad, la adversidad y la muerte. A estas finalidades asistenciales se unieron pronto otras de carácter profesional, primero como rezadores de oraciones y después (ya en el siglo XVIII) como vendedores de pliegos sueltos. Las hermandades derivarían así en corporaciones gremiales, en las que la

50. Synodo de la diocesi de Segonia celebrado por Don Andrés de Cabrera y Bonadilla, Obispo de Segonia, Electo Arçobispo de Çaragoça (Barcelona: Hubert Gotard, 1587), fol. 87.

Ediciones Universidad de Salamanca / అ@@ Stud. his., H. ${ }^{a}$ mod., 43, n. 1 (2021), pp. 293-322 
JUAN GOMIS Y EVA ROMERO

LAS HERMANDADES DE CIEGOS ORACIONEROS EN LA ESPAÑA MODERNA:

ENTRE LA POBREZA Y EL PRIVILEGIO

regulación del oficio devino una prioridad. El apoyo concedido por las autoridades (municipales, eclesiásticas y reales) al desempeño de estas actividades, especialmente a través de la concesión de monopolios, respondió no solo a una voluntad de amparo y de mitigación de la mendicidad, sino quizá también (tal y como hemos sugerido) a una estrategia de control sobre la difusión de ideas heterodoxas, supersticiosas o subversivas.

La adopción de una perspectiva atenta al fenómeno asociacionista al abordar el estudio de la figura del ciego oracionero o coplero en la España Moderna, arroja, pues, nuevas luces para mejorar nuestra comprensión de un fenómeno de mediación cultural que, discurriendo entre la pobreza y el privilegio a través de los siglos fue característico del contexto hispánico.

\section{BIBLIOGRAFÍA}

Álvarez, F. M. (2001). Literatura y Realidad: el Ciego Rezador. Revista de Estudios Extremeños, 62, 219-231.

Benítez Bolorinos, M. (1998). Las cofradias medievales en el Reino de Valencia (13291458). Alicante: Universidad de Alicante.

Benítez Bolorinos, M. (2006). Las cofradías en el Reino de Valencia: análisis y claves interpretativas. Anuario de Estudios Medievales, 36(2), 553-581.

Bofarull y de Sartorio, M. (1876). Gremios y cofradias de la antigua Corona de Aragón. Barcelona: Imprenta del Archivo.

Bolufer, M. (2002). Entre historia social e historia cultural: la historiografía sobre pobreza y caridad en la época moderna. Historia Social, 43, 105-127.

Botrel, J.-F. (1973). Les aveugles, colporteurs d'imprimés en Espagne. I. La confrérie des aveugles de Madrid et la vente des imprimés, du monopole à la liberté du commerce (1581-1836). Mélanges de la Casa de Velázquez, 9, 417-482.

Botrel, J.-F. (1974). Les aveugles, colporteurs d'imprimés en Espagne. II. Des aveugles considérés comme mass-media. Mélanges de la Casa de Velásquez, 10, 233-271.

Cajani, L. (1979). Gli statuti della compagnia dei ciechi, zoppi e stroppiati della Visitazione (1698). Ricerche per la storia religiosa di Roma, 3, 281-313.

Cajani, L. (1994). Compagnia di Santa Maria del Giglio detta dei Ciechi. En L. Artusi y A. Patruno (eds.), Deo gratias. Storia, tradizioni, culti e personaggi delle antiche confraternite fiorentine (pp. 250-253). Roma: Newton Compton.

Carnelos, L. (2016). Street Voices. The Role of Blind Performers in Early Modern Italy. Italian Studies, 71, 184-196.

Cátedra, P. (2002). Invención, Difusión y Recepción de la Literatura Popular Impresa (Siglo XVI). Mérida: Editora Regional de Extremadura.

Cavillac, M. (1979). La reforma de la Beneficencia en la España del siglo XVI: la obra de Miguel Giginta. Estudios de Historia Social, 10-11, 7-59.

Ediciones Universidad de Salamanca / @®@@ Stud. his., H. ${ }^{a}$ mod., 43, n. 1 (2021), pp. 293-322 
JUAN GOMIS Y EVA ROMERO

LAS HERMANDADES DE CIEGOS ORACIONEROS EN LA ESPAÑA MODERNA:

ENTRE LA POBREZA Y EL PRIVILEGIO

Cessi, R. (1905). La Fraglia dei ciechi in Padova. Bollettino del Museo Civico di Padova, $8,105-114$.

Ciruelo P. de (1551). Reprobacion de las supersticiones y hechizerias. Libro muy útil, y necesario a todos los buenos christianos. El qual compuso, y escrinio el Reuerendo Maestro Ciruelo: Canonigo Theologo en la sancta yglesia catedral de Salamanca: $y$ agora de nueno renisto y corregido y añadido algunas mejorías. Con sus actotaciones por las márgenes. Medina del Campo: Guillermo de Millis.

Díaz Cassou, P. (1897). Pasionaria murciana. La Cuaresma y la Semana Santa en Murcia. Madrid: Imprenta de Fortanet.

Espejo, C. (1925). Pleito entre ciegos e impresores (1680-1755). Revista de la Biblioteca, Archivo y Museo, 2, 206-236.

Espinel, V. (1999). Relaciones de la vida del escudero Marcos de Obregón. Madrid: Real Academia Española.

Fernández Iglesias, J. L. (2008). Historia, discapacidad y valía. En J. A. Ledesma (ed.), La imagen social de las personas con discapacidad. Estudios en homenaje a José Julián Barriga Bravo (pp. 177-210). Madrid: CINCA.

García, C. (1998). La desordenada codicia de los bienes ajenos, edición de V. Roncero López. Pamplona: Universidad de Navarra.

Gestoso y Pérez, J. (1910). Curiosidades antiguas sevillanas (serie segunda). Sevilla: El Correo de Andalucía.

Gilard-Fito, C. (2002). La confrérie des musiciens de Sarrant aux 16 et 17 siècles. Bulletin de la Société Archéologique, Historique, Litteraire E Scientifique du Gers, 3, 304-338.

Gomis, J. (2010). Intermediarios entre el texto y su público: la cofradía de pobres ciegos oracioneros de Valencia. En A. Castillo y J. Amelang (dirs.), Opinión pública y espacio urbano en la Edad Moderna (pp. 301-317). Gijón: Trea.

Gomis, J. (2015). Menudencias de imprenta. Producción y circulación de la literatura popular (Valencia, siglo XVIII). Valencia: Institució Alfons el Magnànim.

Gomis, J. (2019). Pious voices: Blind Spanish prayer singers. Renaissance Studies, 33, 42-63.

Grell, O. P. y Cunningham, A., eds. (1997). Health Care and Poor Relief in Protestant Europe, 1500-1700. Londres: Routledge.

Grell, O. P., Cunningham, A. y Arrizabalaga, J., eds. (1999). Health Care and Poor Relief in Counter-Reformation Europe. Londres: Routledge.

Guedes, F. (2005). Os Livreiros em Portugal e as suas associaçôes desde o século XV até aos nossos días. Lisboa: Verbo.

Iglesias Castellano, A. (2016). El ciego callejero en la España Moderna: balance y propuestas. LaborHistórico, 2(1), 74-90.

Iglesias Castellano, A. (2017). Los ciegos: profesionales de la información. Invención, producción y difusión de la literatura de cordel (siglos XVI-XVIII). En G. Ciappelli y V. Nider (coords.), La invención de las noticias: las relaciones de sucesos entre la literatura y la información (siglos XVI-XVIII) (pp. 467-490). Trento: Università degli Studi di Trento.

Ediciones Universidad de Salamanca / @®@@ Stud. his., H. ${ }^{a}$ mod., 43, n. 1 (2021), pp. 293-322 
JUAN GOMIS Y EVA ROMERO

LAS HERMANDADES DE CIEGOS ORACIONEROS EN LA ESPAÑA MODERNA

ENTRE LA POBREZA Y EL PRIVILEGIO

Jiménez de Gregorio, F. (1950-51). Incidencias en algunos gremios y cofradías de Murcia a finales del siglo XVIII. Aportación documental inédita a su Historia. Anales de la Universidad de Murcia, 217-242.

Llordén, A. y Souvirón, S. (1969). Historia documental de las cofradias y hermandades de Pasión de la ciudad de Málaga (pp. 103-104). Málaga: Ayuntamiento de Málaga.

Londoño, M. (2019). Las oraciones censuradas. Superstición y devoción en los indices de libros probibidos de España y Portugal (1551-1583). Barcelona: Herder.

Luján, M. (1956). Segunda parte de la vida del pícaro Guzmán de Alfarache. Madrid: Aguilar.

Metzler, I. (2013). A Social History of Disability in the Middle Ages: Cultural Considerations of Physical Impairment. New York y Abingdon: Routledge.

Olózaga, S. (1864). Estudios sobre elocuencia, política, jurisprudencia, historia y moral (pp. 115-135). Madrid: A. de San Martín y Agustín Jubera.

Pérez de Herrera, C. (1975). Amparo de pobres, edición de M. Cavillac. Madrid: EspasaCalpe.

Ramírez de Arellano y Gutiérrez, T. (1873). Paseos por Córdoba, o sean apuntes para su historia. Córdoba: Imprenta de Rafael Arroyo.

Rico, F., ed. (2005). Lazarillo de Tormes. Madrid: Cátedra.

Romeiras, M. (2014). The allowed cities: spaces and performances of blind citizens in the pre and post-earthquake Lisbon (1755). En S. Adorno, G. Cristina y A. Rotondo (eds.), VisibleInvisible: percepire la città tra descrizioni e omisioni (pp. 1653-1660). Catania: Scrimm.

Tausiet, M. (2004). Ponzoña en los ojos: brujería y superstición en Aragón en el siglo XVI. Madrid: Turner.

Tausiet, M. (2007). Abracadabra omnipotens: magia urbana en Zaragoza en la Edad Moderna. Madrid: Siglo XXI de España.

Vives, J. L. (1992). Del socorro de los pobres. Barcelona: Hacer.

Weigand, Z. (2003). Vivre sans voir. Les aveugles dans la société française, du Moyen Age au siècle de Lonis Braille. Paris: Créaphis.

Zardin, D. (1996). La mendicità tollerata. La 'scola' milanese dei ciechi di S. Cristoforo e le sue regole (sec. XVI-XVIII). En F. Ruggeri (ed.), Studi in onore di mons. Angelo Majo (pp. 355-380). Milan: NED.

Ediciones Universidad de Salamanca / 요 Stud. his., H. ${ }^{a}$ mod., 43, n. 1 (2021), pp. 293-322 